\title{
In vitro Plant Regeneration of thanks giving Cactus [Schlumbergera truncata (Haw.) Moran] from Sliced Segment Section for Shoot Proliferation
}

\author{
N. Deeksha Raj*, B. N. Sathyanarayana and P. Venkatesha Murthy and V. Ramesha
}

University of Agricultural Sciences, Bengaluru, Department of Horticulture, UAS, GKVK, Bengaluru, India

*Corresponding author

\begin{abstract}
A B S T R A C T
Keywords

Cactus, In vitro, Shoot proliferation, Regeneration, Sliced segment section

\section{Article Info}

Accepted:

15 July 2020

Available Online:

10 August 2020

In vitro plant regeneration of Schlumbergera truncata was initiated from the different segment of the Phylloclades. Direct regeneration was observed in MS media containing different concentrations of growth regulators BAP with constant $0.1 \mathrm{mg} / \mathrm{l} \mathrm{NAA}$. Early shoot proliferation was found in longitudinally sliced segment section (61.83) and late response was found in transversely sliced segment section (72.35). The highest number of shoot was recorded in media containing $3 \mathrm{mg} / \mathrm{l}$ of BAP with constant $0.1 \mathrm{mg} / \mathrm{l} \mathrm{NAA}$ at 30,60 and 90 days $(1.45,2 \& 3.22)$. There is no shoot proliferation was recorded in control treatment (without hormones) at 30 and 60 days of culture. After 60 days of initiation, least shoot emergence was recorded in control treatment (GR1) devoid of hormones $(0.22)$.
\end{abstract}

\section{Introduction}

Cactus is a member of the family Cactaceae, comprising of 127 genera with some 1750 known species of the order Caryophyllales which are native to America. Most of the varieties expectedly exist in dry, arid and even desert regions, in almost every part of the world. They are extensively cultivated not only for the rare beautiful flowers but also for its economic importance. They do grow in the wild, but are now also protected in conservatories and nurseries for marketing purpose. Its largest concentration is found around at the latitude of $30^{\circ}$ North and $30^{\circ}$ South of the equator. South Africa and subtropical North and South American house the highest number of species and as well as being densely populated (Mauseth, 2007).

Cacti have fleshy succulent stems that are major organs of photosynthesis. They have absent, small or transient leaves and flowers with ovaries that lie below the sepals and petals, often deeply sunken into a fleshy receptacle (The part of the stem from which the flower parts grow). Cacti show many adaptations to conserve water. Almost all 
cacti are succulents, meaning they have thickened, fleshy parts adopted to store water. Most species of cacti have lost true leaves, retaining only spines, which are highly modified leaves. As well as defending against herbivores, spines help to prevent water loss by reducing airflow close to the cactus and providing some shade. In the absence of leaves, enlarged stems carry out photosynthesis. All cacti have areoles highly specialized short shoots with extremely short internodes in few inches underground.

Thanks giving cactus [Schlumbergera truncata (Haw.) Moran.] is a dicotyledonous perennial plant with specialised features adapted for survival in arid and other climatic conditions. It is also known as "Christmas cactus". This cactus bears white, pink, yellow, orange, red and purple coloured flowers. It is endemic to a small area of the coastal mountains of south-eastern Brazil, having a medicinal use of soothing and relieving pain and also they adapt well to indoor conditions with modest care (Dole and Wilkins, 1999). They are economically important in several countries. Major countries for production of ornamental cacti include Denmark, USA, Japan, Great Britain, Germany and Holland.

Wild Schlumbergera grow either on trees (Epiphytic) or on rocks (Epilithic) and can form sizeable shrubs with woody bases. The plants are leafless, the green stems acting as photosynthetic organs. The stems are composed of segments which are strongly flattened (Cladodes), being made up of a central core with two or more rarely three "wings". Special structures characteristic is called "areoles"; they occur at the ends of the segments with pointed teeth flowers. Whose upper side is differently shaped from the lower side (Zygomorphic).

Christmas cactus plants can be propagated both sexually and asexually. Reproduction via seed is a very slow process and also it is difficult to obtain germination. The setting of seed in the plant is not regular and it takes 1 to 2 years for seed germination, which are owing to limited favourable condition for flowering and seed production (Jenkins, 1993).

The conventional methods of propagation by seeds and cuttings are often inadequate to meet the commercial demands in the world market. As it is laborious and costly affair to produce good number of plants and hence they are sold at higher price (300 Rs/Plant and Grafted 500 Rs/Plant).

In vitro propagation is a potential alternative for production of these plants on large scale in a shorter period of time with the limited space (Hubstenberger et al., 1992). General micro propagation methods by using vegetative parts of the plants have been reported in Schlumbergera (Johnson, et al., 1976a; Balch et al., 2012; Loro et al., 1999). While axillary and adventitious shoots in Schlumbergera have been produced in vitro from phylloclade, from shoot tips (Sridevy and Margrethe, 2004; Johnson et al., 1976b). Explant position and growth regulator have a strong influence on the in vitro morphogenic response. Moreover, micro propagated plants retain the genetic constitution of the mother plant with clonal fidelity.

\section{Materials and Methods}

The present investigation on In Vitro plant regeneration of Thanks giving Cactus [Schlumbergera truncata (Haw.) Moran] from sliced segment section for Shoot proliferation was carried out at the Plant Tissue Culture Laboratory, Division of Horticulture, University of Agricultural Sciences, GKVK (Gandhi Krishi Vignana Kendra) Campus, Bengaluru-65, during 2016-17. 
The cactus plants of Schlumbergera truncata (Haw.) Moran. was procured from, IndoAmerican Hybrid Seed Company Ltd. Bengaluru India, and maintained in greenhouse of the Plant Tissue Culture Laboratory, when the experiment started, the plants were about one-year-old with 4 to 5 tiers of mature modified shoots (leaves) plate 1.

A stock solution was prepared by dissolving $10 \mathrm{mg}$ of 6-benzyle amino purine (BAP) in few drops of $1 \mathrm{~N} \mathrm{NaOH}$ solution. Distilled water was added to make up the solution 100 $\mathrm{ml}$. The media used containing macro and micro salts according to the Murashige and Skoog (1962) medium.

The $\mathrm{P}^{\mathrm{H}}$ of the medium was adjusted to 5.6-5.8 with drop wise of $0.1 \mathrm{~N} \mathrm{NaOH}$. It was then dispense in to culture vessels and autoclaved at $15 \mathrm{psi}$ pressure at $121^{\circ} \mathrm{C}$ for $22 \mathrm{~min}$. Cultures was maintained at $27 \pm 2^{\circ} \mathrm{C}$ under florescent light.

Surface sterilisation was carried out under aseptic condition just before inoculation. The shoots of longitudinal and transverse sliced segment section were transferred separately to the bottle containing 100 to $200 \mathrm{ml}$ of distilled water having 1.5 per cent $(\mathrm{w} / \mathrm{v})$ active chlorine from sodium hypochlorite solution with 1 to 2 drops (v/v) of wetting agent Tween 20. These bottles were continuously shaken for duration of $15 \mathrm{~min}$. The explants were then thoroughly washed five times in sterile distilled water. After this, the shoots were transferred to sterile bottles containing freshly prepared 0.1 per cent $(\mathrm{v} / \mathrm{v})$ Mercuric chlorite (surface sterilant) and were soaked for 2-3 min with intermittent shaking. The solution was drained and the explants were washed 4-5 times with sterile distilled water to remove all the traces of chemical from the surface. These explants were then transferred on to 70 per cent $(\mathrm{v} / \mathrm{v})$ ethanol solution for a quick period of $5 \mathrm{sec}$. Then immediately they were transfer to sterile Double Distilled Water (DDW) and thoroughly rinsed by passage of 5 times (Johnson and Emino, 1979; Havel and Kolar, 1983; Juarez and Passera, 2002) plate 2.

The sterilised stem cuttings were directly placed on medium consisting of MS salts (Murashige and Skoog, 1962) supplemented with 3 per cent $(\mathrm{w} / \mathrm{v})$ sucrose and the media were solidified by 0.6 per cent agar having different concentrations of growth regulators cytokinins 1, 3, and 5mg/l (BAP-6 Benzyl amino purine) with $0.1 \mathrm{mg} / \mathrm{l}$ of auxin (NAANaphthalene Acetic Acid) constant were tested for shoot proliferation. This was carried out under sterile condition in laminar air flow and this culture vessel were kept in photoperiod of $16 \mathrm{~h} \mathrm{light}$ and $8 \mathrm{~h}$ dark at $26 \pm$ $2^{\circ}$ under growth room.

\section{Results and Discussion}

We initiated this experiment to determine effect of different explant viz., longitudinal and transverse sliced segment section that regulate shoot proliferation for massive propagation, which is most popular method for commercial production for a number of cacti species (Fay et al., 1995, Malda et al., 1999, pe' rez- Molphe-Batch and Da villaFigueroa, 2002).

The shoot proliferation response achieved varied significantly in longitudinal and transverse explants used in the experiment. Early shoot proliferation of 61.83 day was observed in longitudinally sliced segment section and late of 72.35 days was observed in transverse sliced segment section. It is an established fact that the tissues at different segment of the stem and different organs are disposed variedly in their ability of the cell metabolism (George and Sherrington, 1984) (Fig. 1-3). 
Table.1 Effect of sliced segment section(s), of the explant and different concentrations of growth regulator (GR), on number of shoot proliferation per explant at 30, 60, and 90 days after culture

\begin{tabular}{|c|c|c|c|}
\hline \multirow[b]{2}{*}{ Treatment } & \multicolumn{3}{|c|}{ Total number of shoot Proliferation per explant } \\
\hline & 30days & 60days & 90days \\
\hline \multicolumn{4}{|c|}{ Sliced stem segment section (S) } \\
\hline $\mathbf{S}_{1}$ & $0.71(1.26)$ & $1.22(1.41)$ & $2.13(1.67)$ \\
\hline $\mathbf{S}_{\mathbf{2}}$ & $0.52(1.19)$ & $0.65(1.23)$ & $1.3(1.43)$ \\
\hline F- table & NS & * & $*$ \\
\hline S. Em. \pm & - & $0.11(0.035)$ & $0.15(0.04)$ \\
\hline CD@0.05\% & 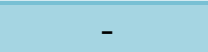 & $0.32(0.098)$ & $0.44(0.12)$ \\
\hline \multicolumn{4}{|c|}{ Growth regulator concentration (GR) } \\
\hline $\mathbf{G R}_{1}$ & $0(1)$ & $0(1)$ & $0.22(1.09)$ \\
\hline $\mathbf{G R}_{\mathbf{2}}$ & $0.6(1.22)$ & $1(1.35)$ & $1.87(1.62)$ \\
\hline $\mathbf{G R}_{\mathbf{3}}$ & $1.45(1.52)$ & $2(1.66)$ & $3.22(1.97)$ \\
\hline $\mathbf{G R}_{4}$ & $0.42(1.16)$ & $0.75(1.27)$ & $1.55(1.53)$ \\
\hline F -value & * & * & * \\
\hline S.Em. \pm & $0.12(0.04)$ & $0.16(0.05)$ & $0.22(0.06)$ \\
\hline CD@ $0.05 \%$ & $0.34(0.12)$ & $0.45(0.13)$ & $0.62(0.17)$ \\
\hline
\end{tabular}

C.D at $\mathrm{P}=0.05$ NS: Non-significant *: Significant

CD: Critical difference S. Em. \pm : Standard error mean

$\mathrm{S}_{1}$ : Longitudinally sliced stem segment section

$\mathrm{S}_{2}$ : Transversely sliced stem segment section

$\mathrm{GR}_{1}$ : Half strength MS media without hormones (Control)

$\mathrm{GR}_{2}$ : Half strength MS media with $1 \mathrm{mg} / \mathrm{l} \mathrm{BAP}+0.1 \mathrm{mg} / \mathrm{l} \mathrm{NAA}$

$\mathrm{GR}_{3}$ : Half strength MS media with $3 \mathrm{mg} / \mathrm{l} \mathrm{BAP}+0.1 \mathrm{mg} / \mathrm{l} \mathrm{NAA}$

$\mathrm{GR}_{4}$ : Half strength MS media with $5 \mathrm{mg} / \mathrm{l} \mathrm{BAP}+0.1 \mathrm{mg} / \mathrm{l} \mathrm{NAA}$

Fig.1 Plant material of Thanks Giving Cactus [Schlumbergera truncate (Haw.) Moran.] procured from Indo American Hybrid Seed Company Ltd

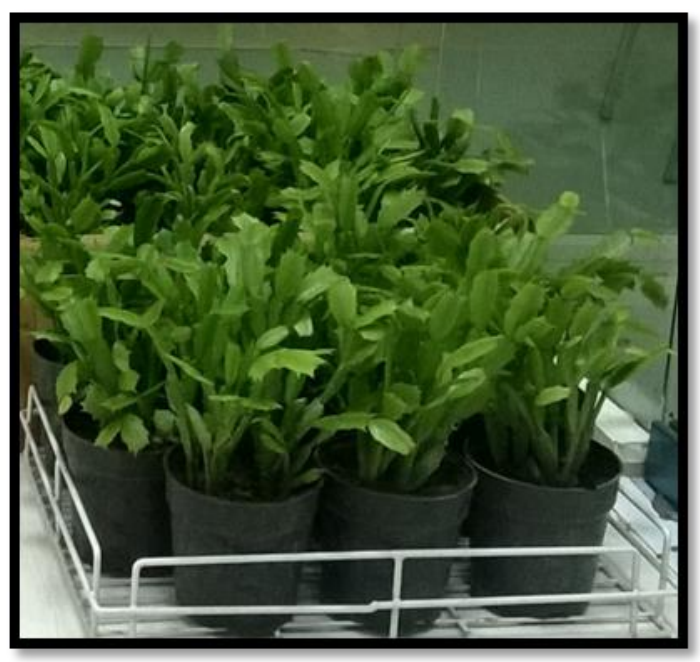


Fig.2 Sectioning of shoots for preparation of different types of explant

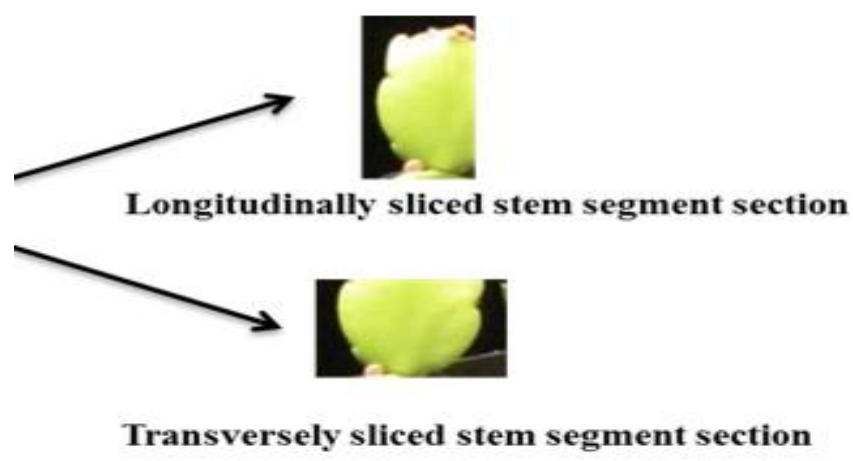

Fig.3 Effect of different explantation days taken for shoot proliferation

Number of days taken for shoot for shoot proliferation

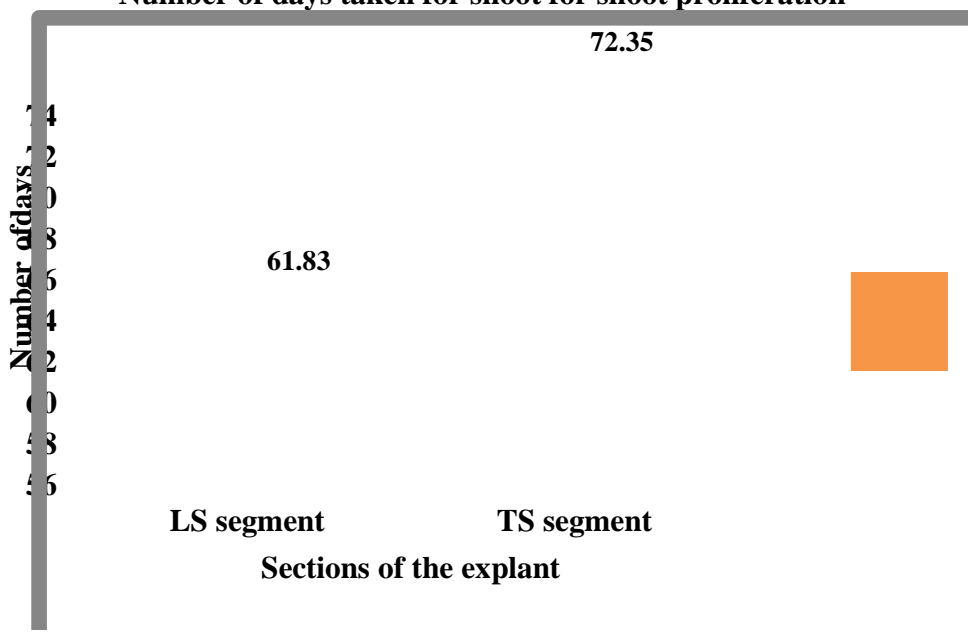

Fig.4 Effect of different concentrations of BAP on days taken for shoot proliferation

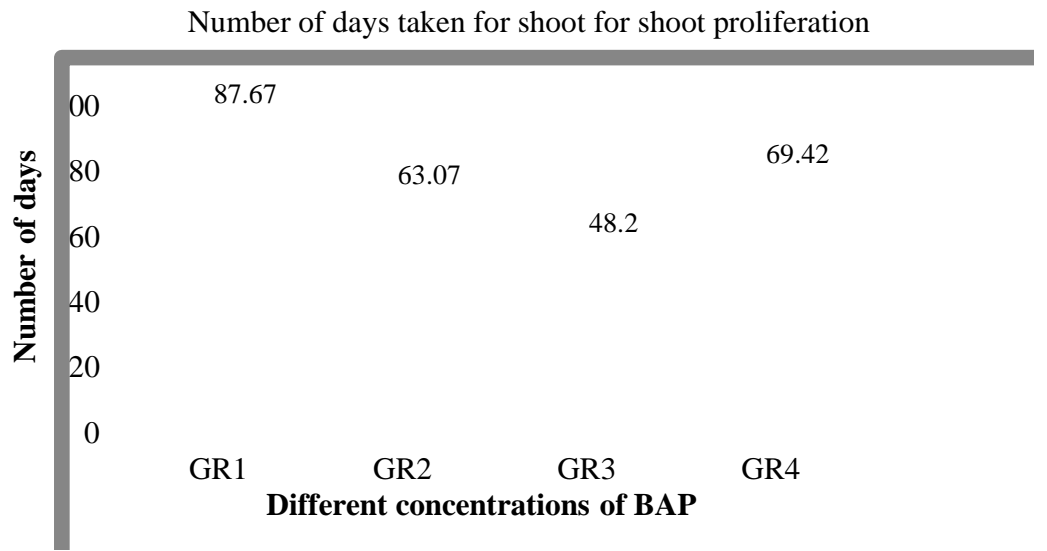


Fig.5 Effect of different explant and different concentrations of growth regulator (BAP) on shoot proliferation per explant at 30,60 and 90 days after culture

Fig.5a Shoot proliferation from longitudinally sliced segment section of the explant at 30, 60 and 90 days after culture

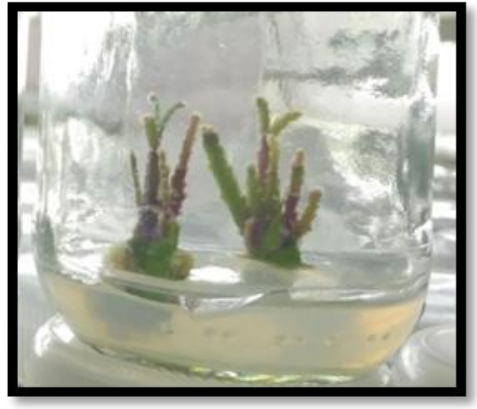

30 days

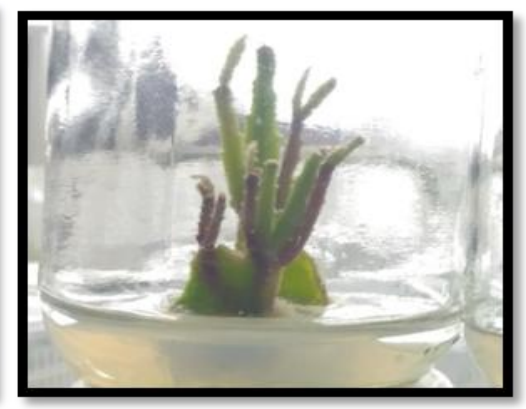

60 days

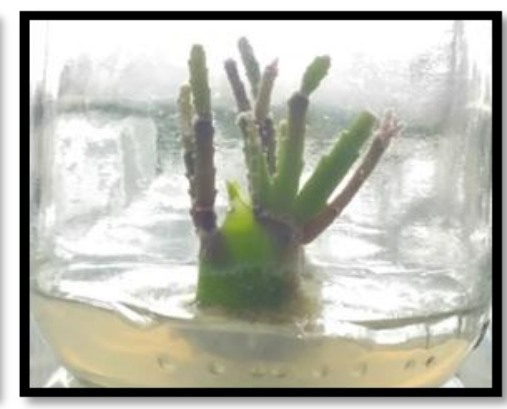

90 days

Fig.5b Shoot proliferation from transversely sliced segment section of the at 30, 60 and 90 days after culture

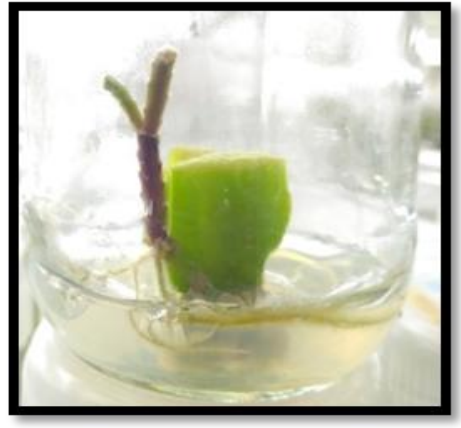

30 days

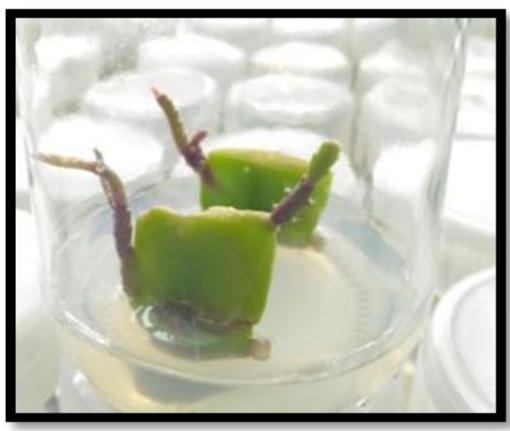

60 days

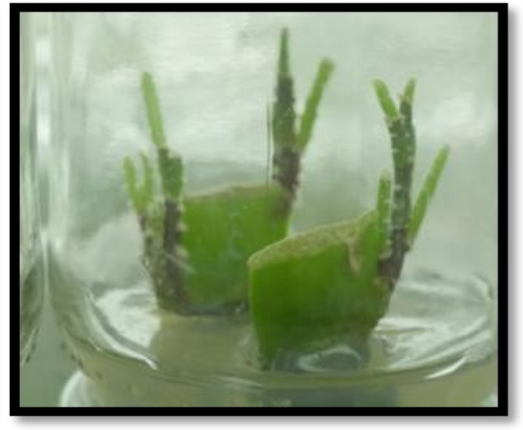

90 days
Among the varied concentrations of growth regulators in the media, BAP at $3 \mathrm{mg} / \mathrm{l}\left(\mathrm{GR}_{3}\right)$ resulted in shoot proliferation as early as 48.2 days as shown in the figure 4 . But in the media without BAP $\left(\mathrm{GR}_{1}\right)$ shoot proliferation occurred as late as 87.67 days.

Concentrations of BAP showed a significant influence on shoot proliferation. Among the different concentrations, $3 \mathrm{mg} / \mathrm{l}$ of $\mathrm{BAP}\left(\mathrm{GR}_{3}\right)$ was found to be the best with increased shoot proliferation among the section of the shoots. The maximum shoot proliferation was obtained in 3mg/l of BAP 1.45, 2.00 and 3.22 at 30, 60 and 90 days after culture as compare to control $(0,0,0.22$ mean number of shoot),
$1 \mathrm{mg} / 1$ (0.6, 1.00, 1.87 mean number of shoot) and in $5 \mathrm{mg} / \mathrm{l}(0.42,0.75,1.55$ mean number of shoots at 30, 60 and 90 days after culture). The response for shoot proliferation was very poor with devoid of BAP in the stem cutting the result here is once again suggestive of the fact that the concentration of BAP is by far the most influencing factor in inducing shoot proliferation as shown in the figure 5 and Table 1. Greater shoot proliferation in cactus species with BAP has also been reported earlier (Perez et al., 2002).

In conclusion the present experiment reveals the significant results on effect of plant growth regulator on different sections of the 
Phylloclades for shoot proliferation. As the growing tip's natural inclination towards morphogenesis owing to increased concentration of growth substances such as hormones may have facilitated the early morphogenic response observed in the present experiment.

\section{References}

Balch, P. M., Eugenio, Perez, M. E. and Lourdes, M. D., 2012, In vitro conservation of Turbinicarpus (Cactaceae) under slow growth conditions. BioOne, 33(2): 45-78.

Dole, J. M. and Wilkins, H.F., 1999. Floriculture: principles and species. Prentice-Hall Inc. 13: 25-45

Fay, M. F., Gratton, J. and Atkinson, P.J., 1995. Tissue culture of succulent plantsAn annotated bibliography. Bradleya, 13: $38-42$.

George, E.F. and Sherrington, P.D., 1984. Plant propagation by tissue culture. Exegetics Ltd., 1: 850-1152.

Havel, L. and Kolar, Z., 1983, Micro explant isolation from Cactaceae PCTOC, 2(4): 349-353.

Hubstenberger, J.F., Clayton, P.W. and Phillips, G.C., 1992, Micro-propagation of cacti (Cactaceae). Biotechnology in agriculture and forestry, 44-72.

Jenkins, Tom, 1993, One Plus One. BCSS, 11(1): 20-20.

Johnson, J.L. and Emino, E.R., 1976. In vitro propagation of Mammillaria elongata [Tissue culture, herbaceous ornamentals]. Hort. Science. 65- 86.
Johnson, J.L. and Emino, E.R., 1979, Tissue culture propagation in the Cactaceae. CSSA., 51: 275-277.

Juarez, M.C. and Passera, C.B., 2002. In vitro propagation of Opuntia ellisiana Griff. and acclimatization to field conditions. Biocell, 26(3): 319-324.

Loro, J.F., Del, R. I. and Perez, R. L., 1999, Preliminary studies of analgesic and antiinflammatory properties of Opuntia dillenii aqueous extract. Journal of Ethnopharmacology, 67(2): 213-218.

Malda, G., Suzaan, H. and Backhaus, R., 1999, In vitro culture as a potential method for the conservation of endangered plants possessing Crassulacean Acid Metabolism (CAM). Scientia Horticulturae, 81: 71-87.

Mauseth, J. D., 2007, Tiny but complex foliage leaves occur in many leafless cacti (Cactaceae). IRJPS, 168(6): 845853.

Murashige T., Skoog F., 1962, A revised medium for rapid growth and bio assays with tobacco tissue cultures. Physiologia plantarum, 15(3): 473-97.

Perez M, E. and davila-figueroa, C.A., 2002. In vitro propagation of Pelecyphora aselliformis Ehrenberg and $P$. strobiliformis (Cactaceae). In Vitro Cellular and Developmental BiologyPlant, 38(1): 73-78.

Sridevy, S. and Margrethe, S., 2004, Regeneration from phylloclade explants and callus cultures of Schlumbergera and Rhipsalidopsis. PCTOC, 78: 75-81.

\section{How to cite this article:}

Deeksha Raj, N., B. N. Sathyanarayana and P. Venkatesha Murthy and Ramesha, V. 2020. In Vitro Plant Regeneration of thanks giving Cactus [Schlumbergera truncata (Haw.) Moran] from Sliced Segment Section for Shoot Proliferation. Int.J.Curr.Microbiol.App.Sci. 9(08): 1451-1457. doi: https://doi.org/10.20546/ijcmas.2020.908.166 